\title{
A STUDY IN POLISH HOUSING CONDITIONS. METHODOLOGY AND BUILDING TYPOLOGY CHARACTERISTICS
}

\author{
Ewa Stachura, Assoc. prof., PhD \\ Institute for Built Environment Studies \\ University of Economics in Katowice \\ e-mail: ewa.stachura@ue.katowice.pl
}

\begin{abstract}
The attributes of the housing environment constitute an important part of the quality of living. Flats and houses, as other products, fulfill the complex needs of users, starting with the provision of shelter and a sense of safety, to satisfaction associated with the social context of occupancy and the perception of its aesthetic values. The housing environment, more than other functional aspects of architecture, shapes the structure of modern cities, and its high quality standards are reflected in the urban potential that promotes economic growth.

The new paradigm of sustainable consumption, which is becoming widely popular all over the world, affects housing needs and modifies the housing preferences in Poland. Changes should be monitored in reference to current housing needs in Poland, to have a better view on new trends, as present-day housing conditions affect consumers' needs and preferences. Knowledge of the relations between the qualitative aspects of housing conditions and expectations should support architects, urban planners and local authorities in creating a functional and aesthetic housing environment endowed with the attributes attractive to occupants.

The paper is focused on presenting certain aspects of the present-day housing conditions in Poland. Out of extensive research material resulting from empirical studies, issues that concern the types of settlements, occupancy period, form of ownership (flats or houses) and utilized space have been selected. The derived information enables the evaluation and interpretation of the quality of the housing environment and the occupants' aspirations.
\end{abstract}

Keywords: present-day housing conditions, housing preferences, sustainable consumption paradigm, housing environment quality.

JEL Classification: R21, R31.

Citation: Stachura E., (2013), "A study in Polish housing conditions. Methodology and building typology characteristics". Real Estate Management and Valuation, vol. 21, no. 1, pp. 25-31.

DOI: 10.2478/remav-2013-0004.

\section{Introduction}

European towns have evolved over hundreds of years. In most city centers medieval houses are mixed with modern buildings from later epochs. In Poland, rapid urbanization started in the 19th and 20th Centuries. The dynamic processes of rebuilding and extension that took place after World War II have entirely changed the profile of Polish towns, where many now exhibit a mosaic of architectural forms and urban structures offering many different types of housing environments. An important factor influencing the character of a post-war Polish town, especially after 1970, is the widespread use of prefabricated concrete slabs in new houses and estates. The poor choice of modular elements in buildings all over the country, the rule of constructing only two types of multi-family houses (up to 5 stories high without an elevator or over 5 , in most cases 9 , with an elevator) has led to a homogenized, 
monotonous architecture and urban form with little local context. As mentioned above, prefabrication ceased in the early 1990s along with Poland's transformation to a market economy. This change has reshaped the housing industry and introduced new localization principles.

\section{Methodological grounds for studies on current and expected housing conditions}

The scope of the non-exhaustive studies was a non-random part of the community, i.e., a sample (KACZMARCZYK, 2000). The sample is a deliberately selected part of the population. The process of the sample selection entailed:

1. the description of the population (community), consisting of

- a sample unit: household, accommodating:

1) Single-family house, segment of private, semi-detached house, constructed before 1990,

2) Single-family house, segment of private, semi-detached house, constructed after 1990,

3) Multi-family building constructed between 1945 - 1970,

4) Multi-family building in prefabricated technology constructed after 1970, up to 5 stories high,

5) Multi-family building in prefabricated technology constructed after 1970, over 5 stories high,

6) Terraced houses and infill buildings in the city centre,

7) Multi-family building constructed after 1990, up to 5 stories high,

8) Multi-family building constructed after 1990, above 5 stories high.

- The subject (element) of the studies was a respondent: adult member of the household.

2. description of the sample size. Optimal in consideration of the object of studies, workload, and financial possibilities of the researcher. The size of the sample depends not only on the population size, but also on the degree of its homogeneity. The more homogeneous the population (in view of selected qualities), the smaller the acceptable sample. The size of the sample also depends on the scope of the studies, the space, the number of the planned analyses and distributions within the studied population (MYNARSKI 1995). The sample size was 900.

3. description of the manner of sample selection. The sample was collected in a non-random manner. Non-random selection is primarily based on the researcher's knowledge (the more experienced and knowledgeable the researcher, the more accurate the selection). The selection was made in view of the knowledge of the population parameters. Among non-random methods of sample selection in market studies, the following are used: typical unit selection, quantity selection, target selection, convenient sample selection, and elimination. The studies employed target selection according to occupancy place criteria and building type. The units that were chosen for the studies by means of the target selection based on the information about the population, were those which should be examined because of their attributes (JANSEN, COOLEN, GOETGELUK, 2011). Thus, the elements of the sample were the units that fulfilled the criteria assumed in the study objective.

Table 1

Percentage of households occupying flats in selected categories of building types

\begin{tabular}{|c|c|c|c|c|c|c|c|}
\hline \multicolumn{2}{|c|}{$\begin{array}{l}\text { Single-family } \\
\text { house (private, } \\
\text { semi-detached) }\end{array}$} & \multicolumn{6}{|c|}{ Multi-family house } \\
\hline \multirow[t]{3}{*}{$\begin{array}{c}\text { Before } \\
1990\end{array}$} & \multirow[t]{3}{*}{$\begin{array}{c}\text { After } \\
1990\end{array}$} & \multirow[t]{3}{*}{$\begin{array}{c}\text { Multi- } \\
\text { family } \\
\text { building } \\
\text { between } \\
1945-70 \\
\end{array}$} & \multicolumn{2}{|c|}{$\begin{array}{l}\text { Multi-family } \\
\text { building } \\
\text { prefabricated } \\
\text { technology } \\
\text { after } 1970\end{array}$} & \multirow[t]{2}{*}{$\begin{array}{c}\text { Terraced } \\
\text { houses, infill } \\
\text { building in } \\
\text { the city } \\
\text { centre }\end{array}$} & \multicolumn{2}{|c|}{$\begin{array}{c}\text { Multi-family } \\
\text { building } \\
\text { after } 1990\end{array}$} \\
\hline & & & \multicolumn{2}{|c|}{$\begin{array}{l}\text { Number } \\
\text { of stories }\end{array}$} & & \multicolumn{2}{|c|}{$\begin{array}{l}\text { Number } \\
\text { of stories }\end{array}$} \\
\hline & & & $\mathrm{Up}_{5}$ to & $\begin{array}{c}\text { Over } \\
5\end{array}$ & & $\mathrm{Up}_{5}$ to & $\begin{array}{c}\text { Over } \\
5\end{array}$ \\
\hline 1 & 2 & 3 & 4 & 5 & 6 & 7 & 8 \\
\hline 16.67 & 13.78 & 15.89 & 6.44 & 13.11 & 17.22 & 11.89 & 5.00 \\
\hline
\end{tabular}

Source: Author's own elaboration.

In order to assess the current residential environmental quality it was therefore necessary, as mentioned above, to classify building types according the periods in which they were built, their location and urban form as well as structure (Table 1). Single-family and multi-family houses 
represent two different types of housing environments, which is an important classification criterion. Housing development characteristics in Poland over the last 60 years are very important classification criterion because of the specific period of time that the dwelling was built (WOJTKUN 2008). A critical turning point in time is the beginning of prefabrication in the 1970s, which became a common building practice. The second turning point was in the early 1990s, with the transformation to a market economy. This changed the economic and spatial determinants of housing development. Moreover, it should be emphasized that after the war traditional technology was used in most building construction. All these characteristics strongly influence living conditions.

\section{Housing conditions in Poland: property types and time frames of occupancy}

Knowledge of the settlement type where the house or apartment is situated allows for the analysis of residential conditions in the urban context, showing the kind of facilities offered to inhabitants in particular zones of the town.

Various forms of apartments are found in Polish housing. Before the change in the political and economic systems, cooperative housing associations comprised the major portion flats. After 1990, most of the cooperative flats were sold to their users for a very low (even "symbolic") price, in such an extent that only a few such collectives remain today. Similarly, the number of municipal and company apartments has also significantly decreased. At the same time, developers now offer houses and flats for sale or rent at market prices. While many owners of tenement houses have recovered their properties, developers and private home builders have produced a large number of single-family houses. Low-cost social housing, however, is not available to low-income households because of the relatively high rental costs.

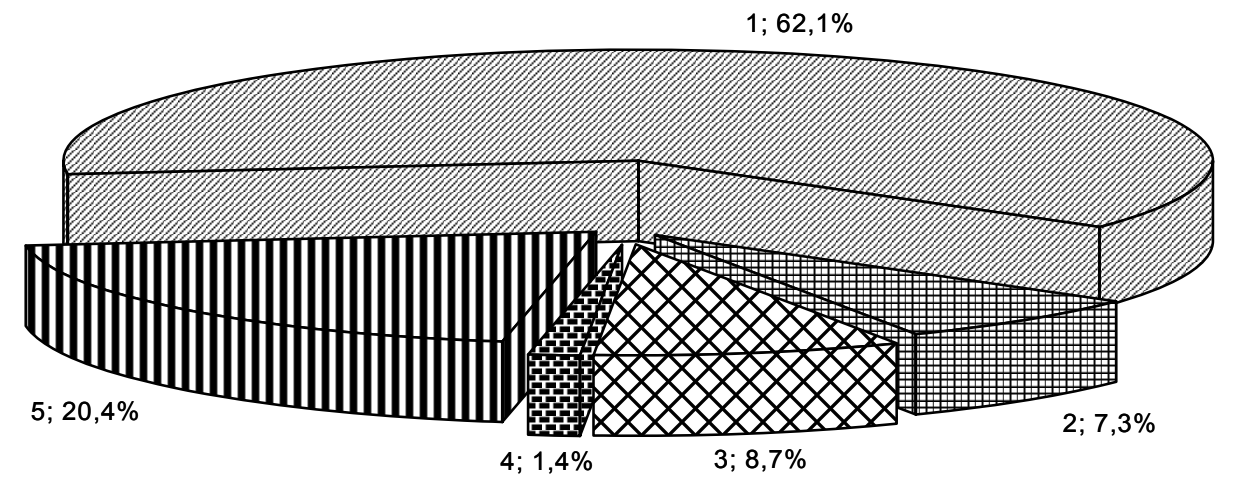

Legend:

Type of property:

. Ownership of the respondent or of a family member

Cooperative ownership

Municipal, employees, business property

Social housing (TBS)

Rental

Fig. 1. Form of property according to the type of the residential building. Source: Author's own research.

When comparing building types with the form of property in the occupied house or apartment segment, more than $90 \%$ of one-family houses and about $50 \%$ of multi-family dwellings are in private property ownership, largely as a result of changes in the housing market over the last 20 years (Fig. 1, 2). The share of private property ownership is the highest in buildings established after 1990 (approximately $60 \%$ ), whereas the lowest share applies to terraced houses or infill buildings situated in the city centres $(37.4 \%)$. It is noteworthy that single-family buildings are rarely rented. And the rental flat figure of around 30\% is almost the same in all types of housing (Fig 2). This phenomenon can be explained when we compare the Polish housing market before and during the transformation. Today, the supply and price of houses/flats is unnaturally high, much higher than the demand. This is the result of owners withholding their house/flat from sale, which represents a form of private investment. Another segment of the housing market purchases flats for rent (investment properties) to 
increase their income. Such a situation creates the danger of a crisis in housing market, similar to the one observed in Spain.

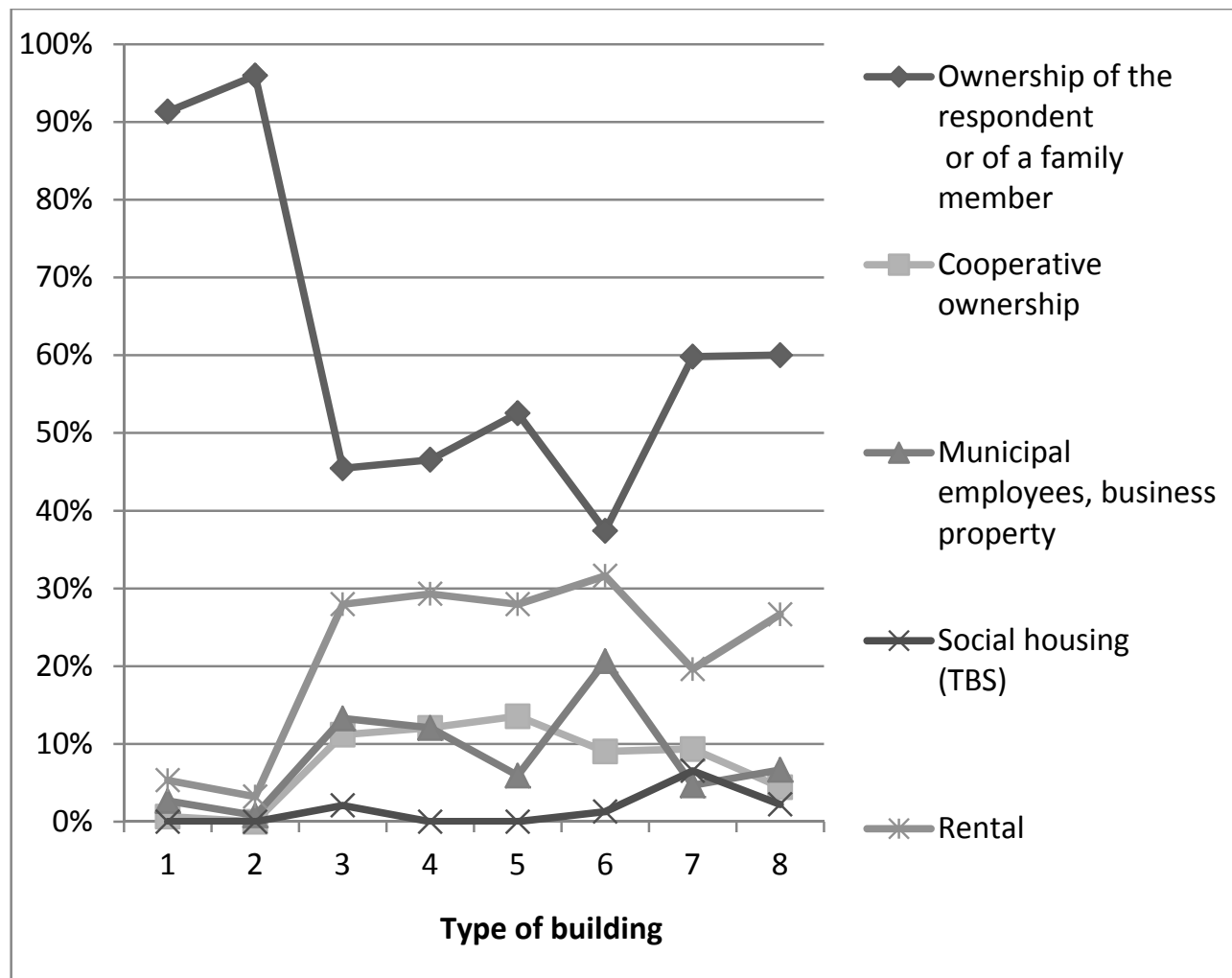

Legend:

*percentage on the categorized plots refers to the category (100\% for each type of building)

Type of building:

1. Single-family house, segment of private, semi-detached, before 1990

2. Single-family house, segment of private, semi-detached, after 1990

3. Multi-family building between $1945-1970$

4. Multi-family building, prefabricated technology after 1970, up to 5 stories high

5. Multi-family building, prefabricated technology after 1970, over 5 stories high

6. Terraced houses, infill building in the city centre

7. Multi-family building after 1990 , up to 5 stories high

8. Multi-family building after 1990, above 5 stories high

Fig. 2. Form of property according to the type of residential building*. Source: Author's own research.

In the case of households dwelling in a house/flat for up to 5 years, almost half of the respondents were renters (49.2\%) and $40.3 \%$ owners. On the other hand, apartments occupied longer than 5 years, regardless of the time interval, $75 \%$ were private properties (Table 2). When analyzing municipal or business flats, the highest share of private ownership occurred when the respondent lived in the flat longer than 30 years and lowest if the period of residence was less than 5 years. These results indicate that the possibility of receiving state assistance in the housing market is limited when compared to the period before the transformation. New social housing (TBS) offers a very small number of flats, most of which are in buildings that are 6 to 10 years old. Although housing cooperatives still exist, a new act that will eliminate this kind of investment and property type is currently being prepared. In buildings common to all the housing categories, the share of cooperative flats is around $5-10 \%$.

There is a correlation between the time the respondents have occupied their houses/flats and the type of the building. The highest percentage of the new occupants (up to 10 years) is observed in multi-family housing built after 1990 which is over 5 stories high (73.3\%) (Fig. 2). When comparing this with buildings of around the same age (but with the different number of stories) it can be seen that the share of inhabitants who dwelled in their flats for 11-20 years is smaller in buildings which are over 5 stories high than in those under 5 . For buildings of more than 5 stories in height, more inhabitants tended to occupy their flats for 10 years or less in comparison with the lower buildings. This may suggest an increase in the density of urban areas in Polish cities. 
Property type and no. years of residence

\begin{tabular}{ccccccc}
\hline \multicolumn{7}{c}{ No. years of residence } \\
\hline $\begin{array}{c}\text { Type of } \\
\text { building }\end{array}$ & Up to $\mathbf{5}$ & $\mathbf{6 - 1 0}$ & $\mathbf{1 1 - 2 0}$ & $\mathbf{2 1 - 3 0}$ & Over 30 & In Total \\
\hline $\mathbf{1}$ & 25 & 13 & 41 & 44 & 27 & 150 \\
\hline $\mathbf{2}$ & $16.67 \%$ & $8.67 \%$ & $27.33 \%$ & $29.33 \%$ & $18.00 \%$ & \\
\hline & 40 & 31 & 42 & 10 & 1 & 124 \\
\hline $\mathbf{3}$ & $32.26 \%$ & $25.00 \%$ & $33.87 \%$ & $8.06 \%$ & $0.81 \%$ & \\
\hline & 51 & 16 & 24 & 27 & 25 & 143 \\
\hline $\mathbf{4}$ & $35.66 \%$ & $11.19 \%$ & $16.78 \%$ & $18.88 \%$ & $17.48 \%$ & \\
\hline $\mathbf{5}$ & 20 & 10 & 12 & 14 & 2 & 58 \\
\hline $\mathbf{5}$ & $34.48 \%$ & $17.24 \%$ & $20.69 \%$ & $24.14 \%$ & $3.45 \%$ & \\
\hline $\mathbf{6}$ & 50 & 17 & 18 & 26 & 7 & 118 \\
\hline $\mathbf{7}$ & $52.37 \%$ & $14.41 \%$ & $15.25 \%$ & $22.03 \%$ & $5.93 \%$ & \\
\hline $\mathbf{8}$ & $35.48 \%$ & $16.13 \%$ & $19.35 \%$ & $17.42 \%$ & $11.61 \%$ & \\
\hline & 47 & 21 & 29 & 7 & 3 & 107 \\
\hline In Total & $27.93 \%$ & $19.63 \%$ & $27.10 \%$ & $6.54 \%$ & $2.80 \%$ & \\
\hline
\end{tabular}

Legend: See Fig. 1.

Source: Author's own elaboration.

It is also interesting to analyze the structure of the occupiers of single-family houses constructed before 1990 in the context of the time they have occupied their houses. In the case of almost half the dwellers $(47.3 \%)$ that lived in their houses for longer than 21 years, these types of buildings were not competitive on the secondary market, because of low technical and technological standards. Singlefamily houses have become a very attractive form of accommodation after 1990. Occupants appreciate the innovative technologies that these building have to offer and the low cost of renovation in comparison to the flats constructed before the transformation.

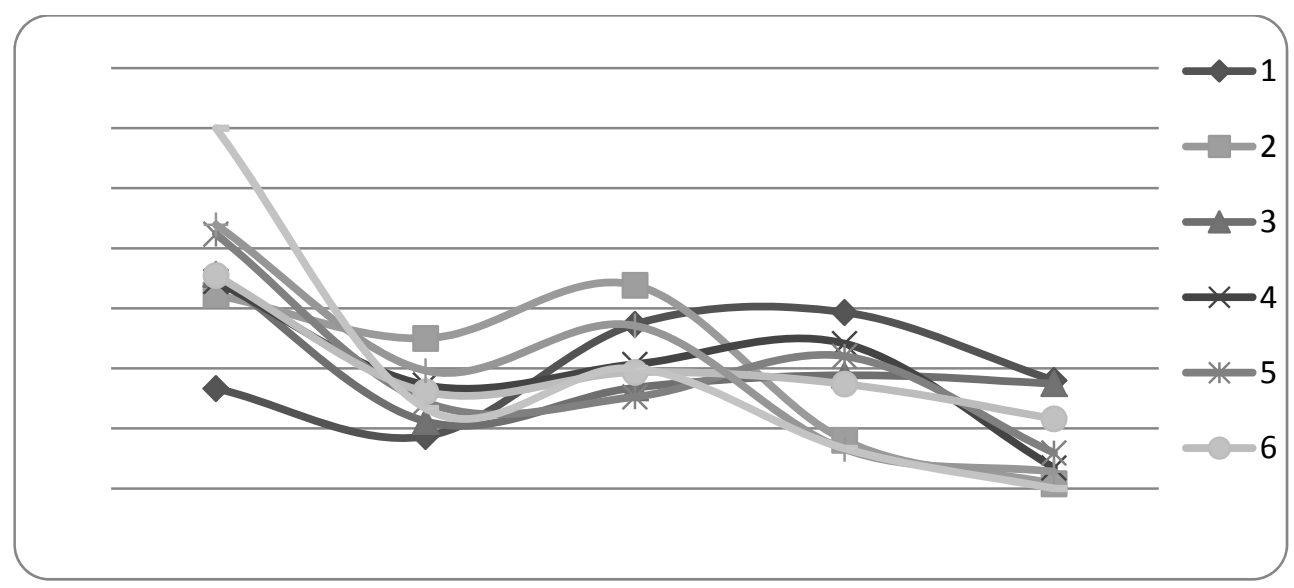

Legend: See Fig.1.

Fig. 2. Building types and the time frames of occupancy. Source: Author's own elaboration.

Figure 2 shows the changes in occupancy times in prefabricated buildings. The research shows that only $25 \%$ of the respondents had occupied multi-family buildings constructed after 1970 for longer than 20 years. The remaining $75 \%$ of the respondents had bought or rented their apartment in the transformation period. This indicates that this type of development is popular and competitive on the 
secondary housing market. It also suggests that, on the whole, housing estates constructed after 1970 offer good or very good access to the community facilities in comparison to newly established housing complexes, even though the dwelling standard is not very high.

\section{Floor area of Polish flats and single-family houses according to the type of building}

The results also show that the average floor area of flats in Poland is not very large. In buildings constructed after World War II, the floor area was limited. For example, single-family houses had floor areas no greater than $120 \mathrm{~m}^{2}$. The housing standards were poor in most buildings constructed before 1990 and the flats were very small. Cooperative flats were allocated depending on the number of household members (the average being 2+2) whereas in the market economy following 1990, the floor area of flats depended on the purchasing power of the household. The research results clearly show that the floor area of flats in Poland is highly differentiated and depends of the type of building (Table 3 , 4). Moreover, the analysis of dwelling size shows that the floor area of flats in buildings constructed after 1990 is higher than characteristic of buildings established between 1945-1990. Single-family houses, for example, in most cases have larger floor areas than flats in multi-family housing and the living area of $42.74 \%$ of one-family houses built after 1990 exceeded $150 \mathrm{~m}^{2}$. City centre terraced houses and infill buildings have small floor areas because after the World War II the apartments were divided into smaller units and granted to families newly arrived in the cities.

Table 3

Percentage of dwelling with given floor areas in various types of buildings*

\begin{tabular}{ccrrrrrrr}
\hline $\begin{array}{c}\text { Type of } \\
\text { Building }\end{array}$ & \begin{tabular}{c} 
Up to \\
\cline { 2 - 8 }
\end{tabular} & $35-50$ & $51-60$ & $61-90$ & $91-120$ & $\begin{array}{c}121- \\
150\end{array}$ & $\begin{array}{c}\text { Over } \\
150\end{array}$ & $\begin{array}{c}\text { In } \\
\text { total }\end{array}$ \\
\hline $\mathbf{1}$ & 4.00 & 4.67 & 4.00 & 22.00 & $\mathbf{2 9 . 3 3}$ & 12.00 & 24.00 & $100 \%$ \\
\hline $\mathbf{2}$ & 0.81 & 4.03 & 1.61 & 9.68 & 20.97 & 20.16 & $\mathbf{4 2 . 7 4}$ & $100 \%$ \\
\hline $\mathbf{3}$ & 16.08 & $\mathbf{4 0 . 5 6}$ & 21.68 & 16.78 & 3.50 & 1.40 & 0.00 & $100 \%$ \\
\hline $\mathbf{4}$ & 12.07 & $\mathbf{4 4 . 8 3}$ & 22.41 & 17.24 & 3.45 & 0.00 & 0.00 & $100 \%$ \\
\hline $\mathbf{5}$ & 21.19 & 22.03 & $\mathbf{3 6 . 4 4}$ & 17.80 & 2.54 & 0.00 & 0.00 & $100 \%$ \\
\hline $\mathbf{6}$ & 13.55 & $\mathbf{3 1 . 6 1}$ & 20.65 & 24.52 & 7.74 & 1.94 & 0.00 & $100 \%$ \\
\hline $\mathbf{7}$ & 6.54 & 23.36 & 28.97 & $\mathbf{3 2 . 7 1}$ & 4.67 & 3.74 & 0.00 & $100 \%$ \\
\hline $\mathbf{8}$ & 6.67 & 26.67 & 24.44 & $\mathbf{3 1 . 1 1}$ & 4.44 & 2.22 & 4.44 & $100 \%$ \\
\hline
\end{tabular}

* The percentage in Table 1 refers to the category (100\% per each type of building) Legend: See Fig.1.

Source: Author's own elaboration.

Percentage of selected ranges of the floor area in various types of buildings*

Table 4

\begin{tabular}{ccrrrrrr}
\hline $\begin{array}{c}\text { Type of } \\
\text { Building }\end{array}$ & $\begin{array}{c}\text { Up to } \\
\mathbf{3 5}\end{array}$ & $\mathbf{3 6 - 5 0}$ & $\mathbf{5 1 - 6 0}$ & $\mathbf{6 1 - 9 0}$ & $\mathbf{9 1 - 1 2 0}$ & $\mathbf{1 2 1 - 1 5 0}$ & $\begin{array}{c}\text { Over } \\
\mathbf{1 5 0}\end{array}$ \\
\hline $\mathbf{1}$ & 6.45 & 3.37 & 3.55 & 17.65 & $\mathbf{4 4 . 4 4}$ & 33.96 & 39.56 \\
\hline $\mathbf{2}$ & 1.08 & 2.40 & 1.18 & 6.42 & 26.26 & $\mathbf{4 7 . 1 7}$ & $\mathbf{5 8 . 2 4}$ \\
\hline $\mathbf{3}$ & 24.73 & $\mathbf{2 7 . 8 8}$ & 18.34 & 12.83 & 5.05 & 3.77 & 0.00 \\
\hline $\mathbf{4}$ & 7.53 & 12.50 & 7.69 & 5.35 & 2.02 & 0.00 & 0.00 \\
\hline $\mathbf{5}$ & $\mathbf{2 6 . 8 8}$ & 12.50 & $\mathbf{2 5 . 4 4}$ & 11.23 & 3.03 & 0.00 & 0.00 \\
\hline $\mathbf{6}$ & 22.58 & 23.56 & 18.93 & $\mathbf{2 0 . 3 2}$ & 12.12 & 5.66 & 0.00 \\
\hline $\mathbf{7}$ & 7.53 & 12.02 & 18.34 & 18.72 & 5.05 & 7.55 & 0.00 \\
\hline $\mathbf{8}$ & 3.23 & 5.77 & 6.51 & 7.49 & 2,02 & 1.89 & 2.20 \\
\hline In Total & $100 \%$ & $100 \%$ & $100 \%$ & $100 \%$ & $100 \%$ & $100 \%$ & $100 \%$ \\
\hline
\end{tabular}

* The percentage in Table 2 refers to the category (100\% per each range of floor area)

Legend: See Fig.1.

Source: Author's own elaboration. 
A variety of residential building types coexist in contemporary Polish towns. The attractiveness of these individual types depends on both urban and architectural characteristics. Although housing constructed in the last 20 years is characterized by good and very good technological standards, its location is worse than in case of the housing complexes constructed before 1990. The ownership type of flats and houses is also differentiated. Most single-family houses are in private ownership, whereas the rental share in multi-family housing is increasing similarly for all building types.

In relation to the change of ownership of cooperative flats mentioned above, the rapid development of new housing estates has caused a significant growth in Poland's housing market. Given the economic and social changes that have taken place, people have started to formulate their housing needs and preferences more precisely. To find the best way of understanding housing development trends, it is necessary to identify the existing housing conditions.

\section{Conclusions}

The paper presents a selected part of research findings on the existing housing environment in Poland. Survey respondents, after providing answers to the questionnaire, were then asked to rank their housing preferences, so that housing preferences could be examined in relation to the current housing (environment) conditions. This method allows for the construction of various correlations, such as those between the existing and expected housing conditions. Models of existing housing conditions might show the spatial structure, dwelling conditions and the surrounding urban environment. The appraisal of current housing conditions and preferences can provide insight into how people perceive the housing environment, its characteristics and range of elements.

The classification of building types allows for correlating selected building categories with the type of property ownership, occupancy period and average floor area in the different housing types. Such knowledge allows us to foresee the future aspirations of dwellers, possible changes in the social structure of housing estates and expected demand in the housing market.

\section{Bibliography}

KACZMARCZYK S., 2000, Badania marketingowe. Metody, techniki (Marketing studies. Methods, Techniques), PWE, Warszawa.

MYNARSKI S., 1995, Badania rynkowe w warunkach konkurencji (Market studies under conditions of competition), Oficyna Wydawnicza Fogra, Kraków.

The Measurement and Analysis of Housing Preference and Choice, 2011, JANSEN S., COOLEN H., GOETGELUK R. (eds.),. Springer Dordrecht Heidelberg, London, New York.

WOJTKUN G., 2008, Wielorodzinne budownictwo mieszkaniowe. Wizje i rzeczywistość (Multi-family Housing. Idea and practise), Wyd. Politechniki Szczecińskiej, Szczecin. 